\title{
Radiological Dose Assessment of Natural Radioactivity in Malaysian Tiles Using Resrad-Build Computer Code
}

(Penilaian Dos Sinaran Keradioaktifan Tabii dalam Jubin di Malaysia Menggunakan Kod Komputer Resrad-Build)

\author{
AZNAN FAZLI ISMAIL*, SHITTU ABDULLAHI, SUPIAN SAMAT \\ \& MUHAMAD SAMUDI YASIR
}

\begin{abstract}
This research reports the annual effective dose of dwellers based on the finding of natural radioactivity concentrations in Malaysian tiles. A total of 30 tiles samples obtained from the manufacturer or bought directly from local hardware store. Natural radioactivity was analyzed using gamma spectrometry system for $12 \mathrm{~h}$ counting times. The activity concentration of ${ }^{226} \mathrm{Ra},{ }^{232} \mathrm{Th}$, and ${ }^{40} \mathrm{~K}$ in the analyzed samples ranged from $37.50-158.05 \mathrm{~Bq} \mathrm{~kg}^{-1}, 42.22-80.19 \mathrm{~Bq} \mathrm{~kg}^{-1}$ and $349.46-$ $750.18 \mathrm{~Bq} \mathrm{~kg}^{-1}$, respectively. The determined radium equivalent activity was below than the recommended limit of 370 $\mathrm{Bq} \mathrm{kg^{-1 }}$. The external dose received by dwellers due to natural radionuclides in tiles were projected for 1, 5, 10, 20 and 50 years through six exposure pathways using Resrad-build computer code. The results showed that the annual effective dose received by dwellers increased for the investigated timelines but still lower than the annual recommended limit of $1500 \mu \mathrm{Sv}$. The simulation result also indicates that radon gas was the primary radiation exposure which contributes 80-94\% from the total radiation exposure to dwellers.
\end{abstract}

Keyword: Annual effective dose; natural radionuclides; Resrad-Build computer code; tiles

ABSTRAK

Kajian ini melaporkan kadar dos yang diterima oleh penghuni bangunan berdasarkan kepekatan radionuklid tabii dalam jubin di Malaysia. Sebanyak 30 sampel jubin telah diperoleh daripada pengeluar atau dibeli secara terus daripada kedai. Kepekatan aktiviti radionuklid tabii dianalisis menggunakan sistem spektrometri sinar gama dengan masa pembilangan selama 12 jam. Kepekatan aktiviti ${ }^{226} \mathrm{Ra},{ }^{232} \mathrm{Th}$, dan ${ }^{40} \mathrm{~K}$ dalam sampel masing-masing berada dalam julat $37.50-158.05$ $\mathrm{Bq} \mathrm{kg-1}, 42.22$ - $80.19 \mathrm{~Bq} \mathrm{~kg}^{-1}$ dan $349.46-750.18 \mathrm{~Bq} \mathrm{~kg}$. Nilai aktiviti kesetaraan radium yang ditentukan adalah di bawah had yang disyorkan ititu $370 \mathrm{~Bq} \mathrm{kg-1}$. Dos dedahan tahunan yang diterima oleh penghuni bangunan berpunca daripada radionuklid tabii dalam jubin telah ditentukan menggunakan kod komputer Resrad-build bagi 1, 5, 10, 20 dan 50 tahun melalui enam laluan dedahan. Keputusan kajian mendapati kadar dos dedahan tahunan yang diterima oleh penghuni meningkat bagi tempoh masa yang dikaji tetapi masih rendah daripada had dos tahunan yang dicadangkan iaitu $1500 \mu \mathrm{Sv}$. Hasil simulasi juga menunjukkan gas radon adalah sumber dedahan sinaran utama yang menyumbang 80-94\% daripada jumlah dedahan sinaran kepada penghuni bangunan.

Kata kunci: Dos dedahan tahunan; jubin; kod komputer Resrad-build; radionuklid tabii

\section{INTRODUCTION}

Studies of natural radiation background considered relevant because it is the primary source of exposure to human kind. About $90 \%$ of radiation exposures come from natural sources such as terrestrial radiation, cosmic radiation, and radon gas. The exposure of the public to natural radiation sources has been estimated to result in an annual effective dose equivalent of $2.4 \mathrm{mSv}$ (UNSCEAR 2000). The building material is one of the sources or radiation exposures to dwellers. Knowledge of radiation levels in buildings is clearly of fundamental importance in the assessment of population exposure, as the majority of individuals spend most time indoors. Building materials can cause significant gamma dose indoors, due to their natural radionuclide content (Trevisi et al. 2012). Though building materials act as radiation attenuator from outdoor radiation, they also contribute to the radiation dose to dwellers, if the building materials used contain a high concentration of natural radioactivity. For this reason, there are many research which reports the natural radionuclide content of building materials over the world. Various studies carried out by other researchers showed that the indoor dose rate would accordingly elevate to the natural radioactivity concentration in building materials (Al-Zahrani 2017; Nisha et al. 2016; Raghu et al. 2017; Senthilkumar et al. 2014; Trevisi et al. 2012). In addition to that, the knowledge on the level of natural radioactivity in building materials is imperative to assess the possible radiological hazard to dwellers and to develop standard and guidelines for the local authority. 
The decorative building materials such as ceramic tiles are popular decorative building materials worldwide due to its reasonable cost. These tiles can be utilized to designs floors, walls, counter tops, fireplaces and walkways. Besides its aesthetic function as a design component, tiles also used as special function as finishing building material. The fabrication of ceramic tiles involves a mixture of materials such as clay, kaolin and silica that has been pressed before heated at high temperature. The quantity of each material in the portion of the tiles is different depending on their function as base materials, as a coloring agent and for other properties. The tiles might be glazed or left unglazed depending on demand. Usually, zircon was used as glazed material in the production of tiles. The presence of zircon in glazed significantly increase the level of natural radioactivity in building material (Righi \& Bruzzi 2006; Turhan et al. 2011; Xinwei 2004).

Therefore, this research aimed to determine the level of the natural radionuclide in tiles and the associated radiological hazard. The radiation dose due to the application of tiles as building materials were also investigated up to 100 years to evaluate the long-term radiological effect.

\section{EXPERIMENTAL DETAILS}

\section{SAMPLING AND SAMPLE PREPARATION}

Samples were obtained from manufacturers or bought directly from local hardware stores. Samples were dried in the oven for $48 \mathrm{~h}$ at $105^{\circ} \mathrm{C}$ until constant weight achieved. Samples were left to cool at room temperature before being sieved with $500 \mu \mathrm{m}$ sieve to ensure the homogeneity of the samples. About 400 - $420 \mathrm{~g}$ of samples were filled into acrylic counting bottles to produce the same geometry as the certified reference materials used in this study. Radioactivity measurements were carried out in the air tight acrylic counting bottles to prevent the release of radon gas. Prior to counting, samples were kept for 30 days to attain secular equilibrium between the parent's radionuclide $\left({ }^{238} \mathrm{U}\right.$ and ${ }^{232} \mathrm{Th}$ ) and their progeny. During the measurements, the counting bottles were placed on the top of the detector to increase the probability of gamma energy detection, since the activities of natural radioactivity are usually low.

\section{DETERMINATION OF NATURAL RADIOACTIVITY}

Natural radioactivity in these samples was determined for $12 \mathrm{~h}$ using a gamma spectrometry system with a Highpurity Germanium (HPGe) detector coupled to multi channel analyzer. The diameter and length of the HPGe crystal were $50 \mathrm{~mm}$ and $31 \mathrm{~mm}$, respectively. The HPGe has enclosed inside a Canberra -747 shielding which constructed with $100 \mathrm{~mm}$ thickness lead coated with 1 and $1.6 \mathrm{~mm}$ of tin and copper, respectively, to provide a low background environment. Gamma spectrometry system was setup to detect an upper limit of $3000 \mathrm{keV}$ photon energy in 16384 channels at a conversion gain of $0.183 \mathrm{keV}$ channel $^{-1}$. Analog pulse was fed into an AFT model 2025 spectroscopy main amplifier operating with a $4 \mu$ s shapping time. Gamma energy photopeak spectrums were searched and identified using Genie-2000 software supplied Canberra. Energy resolution for the $1332.5 \mathrm{keV}$ energy photopeak was 1.80 $\mathrm{keV}$, while the relative efficiency of the detector was $30 \%$. The gamma spectrometry system was calibrated using a mixture of ${ }^{22} \mathrm{Na},{ }^{51} \mathrm{Cr},{ }^{57} \mathrm{Co},{ }^{60} \mathrm{Co},{ }^{85} \mathrm{Sr},{ }^{88} \mathrm{Y},{ }^{109} \mathrm{Cd},{ }^{113} \mathrm{Sn},{ }^{177} \mathrm{Cs}$, ${ }^{123 \mathrm{~m}} \mathrm{Te}$ and ${ }^{241} \mathrm{Am}$ radionuclides. The activity concentration of ${ }^{226} \mathrm{Ra}\left({ }^{238} \mathrm{U}\right.$ series) was determined through $351.9 \mathrm{keV}$ $\left({ }^{228} \mathrm{Ac}\right)$ and $1764.5 \mathrm{keV}\left({ }^{214} \mathrm{Bi}\right)$ energy photopeaks, while ${ }^{232} \mathrm{Th}$ were determined through $911.2 \mathrm{keV}\left({ }^{228} \mathrm{Ac}\right)$ and $2614.5 \mathrm{keV}\left({ }^{208} \mathrm{Tl}\right)$. The activity concentrations of ${ }^{40} \mathrm{~K}$ were determined through $1460.3 \mathrm{keV}$ energy photopeaks. The counting errors were quoted at 1 -sigma absolute. IAEA Soil375 was used as certified reference material in this study. Natural radionuclide concentrations were determined using the equation as reported earlier (Aznan et al. 2010; Majid et al. 2013):

$$
\mathrm{W}_{\mathrm{s}}=\frac{\mathrm{M}_{\mathrm{rm}} \times \mathrm{A}_{\mathrm{s}}}{\mathrm{M}_{\mathrm{s}} \times \mathrm{A}_{\mathrm{rm}}} \times \mathrm{W}_{\mathrm{rm}}
$$

where $\mathrm{W}_{\mathrm{s}}$ and $\mathrm{W}_{\mathrm{rm}}$ are radionuclide concentrations for sample and reference material in $\mathrm{Bq} \mathrm{kg}^{-1} ; \mathrm{M}_{\mathrm{s}}$ and $\mathrm{M}_{\mathrm{rm}}$ are sample and reference material mass $(\mathrm{g})$; while $\mathrm{A}_{\mathrm{s}}$ and $\mathrm{A}_{\mathrm{rm}}$ are activity (net count per second, cps) for sample and reference material, respectively.

\section{RADIOLOGICAL HAZARD INDEX}

Radium equivalent was used to estimate radiological hazard index. The significance of ${ }^{226} \mathrm{Ra}{ }^{232} \mathrm{Th}$, and ${ }^{40} \mathrm{~K}$ concentrations, with respect to radiation exposure, was defined in terms of radium equivalent activity $\left(\mathrm{Ra}_{\mathrm{eq}}\right)$ in $\mathrm{Bq} \mathrm{kg}^{-1} \cdot \mathrm{Ra}_{\mathrm{eq}}$ was calculated using the following equation (Almayahi et al. 2012; Baretka \& Matthew 1985):

$$
\mathrm{Ra}_{\mathrm{eq}}=\mathrm{C}_{\mathrm{Ra}}+1.47 \mathrm{C}_{\mathrm{Th}}+0.077 \mathrm{C}_{\mathrm{K}}
$$

where $\mathrm{C}_{\mathrm{Ra}}, \mathrm{C}_{\mathrm{Th}}$, and $\mathrm{C}_{\mathrm{K}}$ are the activity concentration of ${ }^{226} \mathrm{Ra},{ }^{228} \mathrm{Ra}$ and ${ }^{40} \mathrm{~K}$ in $\mathrm{Bq} \mathrm{kg}{ }^{-1}$, respectively. This equation is based on the estimation that $10 \mathrm{pCi} \mathrm{g}^{-1}$ of ${ }^{226} \mathrm{Ra}, 7 \mathrm{pCi} \mathrm{g}^{-1}$ of ${ }^{232} \mathrm{Th}$ and $130 \mathrm{pCi} \mathrm{g}^{-1}{ }^{40} \mathrm{~K}$ will produce the same gamma dose rate (Almayahi et al. 2012; Baretka \& Matthew 1985). The value of $\mathrm{Ra}_{\text {eq }}$ should be less than $370 \mathrm{~Bq} \mathrm{~kg}^{-1}$ for building material as recommended by NEA-OECD (1979).

\section{RADIOLOGICAL DOSE ASSESSMENT}

Radiological dose assessment was calculated using ResradBuild 3.4 computer code developed by Argonne National Laboratory. Resrad-Build computer code is a pathway analysis designed to evaluate the potential radiological dose incurred by an individual who works or lives in a building contaminated with radioactive material. In this study, the radiation aspect was from the ceramic tiles that covered the whole room floor area. The radiological risk was estimated for 1, 5, 10, 20 and 50 years for dwellers. Exposure duration was set up to annual (365 days) with 
an indoor fraction of 0.8 since most of the people spent $80 \%$ of their daily times in the building. For the room modeling, standard single room geometries with an area of $54 \mathrm{~m}^{2}$. The wall thickness was set to $13 \mathrm{~cm}$. The material density and the daily inhalation rate were set at $2.4 \mathrm{~g} \mathrm{~cm}^{-3}$ and $20 \mathrm{~m}^{3}$, respectively. Default values of deposition velocity, resuspension rate, and air exchange rate were 0.01 $\mathrm{m} \mathrm{s}^{-1}, 5 \times 10^{-7} \mathrm{~s}^{-1}$ and $0.8 \mathrm{~h}^{-1}$, respectively. For the source parameters, the tiles were categorized as volume source with the direction of the radiation was going upward from the floor surface ( $\mathrm{Z}$ direction) with the thickness of $0.7 \mathrm{~cm}$.

\section{RESULTS AND DISCUSSION}

\section{NATURAL RADIONUCLIDE CONCENTRATIONS}

The measured activity concentrations of ${ }^{226} \mathrm{Ra},{ }^{232} \mathrm{Th}$, and ${ }^{40} \mathrm{~K}$ in 30 tiles samples along with radium equivalent activity are shown in Table 1 . The activity concentration of ${ }^{226} \mathrm{Ra},{ }^{232} \mathrm{Th}$ and ${ }^{40} \mathrm{~K}$ in tiles samples were found to be in the range of $37.5 \pm 0.3-158.1 \pm 3.6 \mathrm{~Bq} \mathrm{~kg}^{-1}, 42.2 \pm$ $0.1-80.2 \pm 2.1 \mathrm{~Bq} \mathrm{~kg}^{-1}$ and $349.5 \pm 25.0-750.18 \pm 7.15$ $\mathrm{Bq} \mathrm{kg}^{-1}$, respectively. As shown in Figure 1, the activity concentrations of ${ }^{226} \mathrm{Ra},{ }^{232} \mathrm{Th}$, and ${ }^{40} \mathrm{~K}$ in all samples were measured to be higher than the average world values as reported by UNSCEAR (2000) which were $35 \mathrm{~Bq} \mathrm{~kg}^{-1}$, $30 \mathrm{~Bq} \mathrm{~kg}^{-1}$ and $400 \mathrm{~Bq} \mathrm{~kg}^{-1}$, respectively. Also, these activity concentrations of exceeding the values reported in a previous study conducted in Malaysia (Yasir et al. 2007). Several factors might contribute the concentration of natural radionuclides in tiles such as the selection of raw materials and the addition of glazes on tiles surface. For example, the previous study reported that glazes on tiles surface contain the highest activity concentrations of natural radionuclides compared to other materials in ceramic tiles (Thomas 2000). In addition to that, the used

TABLE 1 . Activity concentrations of ${ }^{226} \mathrm{Ra},{ }^{232} \mathrm{Th}$, and ${ }^{40} \mathrm{~K}$ and radium equivalent $\left(\mathrm{Ra}_{e q}\right)$ in Malaysia tiles

\begin{tabular}{|c|c|c|c|c|}
\hline \multirow{2}{*}{ Sample ID } & \multicolumn{3}{|c|}{ Activity concentration $\left(\mathrm{Bqkg}^{-1}\right)$} & \multirow{2}{*}{$\frac{\text { Raeq }\left(\text { Bgkg }^{-1}\right)}{157.63 \pm 5.32}$} \\
\hline & ${ }^{226} \mathrm{Ra}$ & ${ }^{232} \mathrm{Th}$ & ${ }^{40} \mathrm{~K}$ & \\
\hline 1 & $48.07 \pm 0.65$ & $91.55 \pm 3.27$ & $658.76 \pm 16.80$ & $200.17 \pm 5.08$ \\
\hline 2 & $81.73 \pm 2.98$ & $51.67 \pm 0.92$ & $578.56 \pm 10.25$ & $146.0 \pm 2.02$ \\
\hline 3 & $37.50 \pm 0.33$ & $53.28 \pm 0.6$ & $419.59 \pm 3.0$ & $190.91 \pm 2.02$ \\
\hline 4 & $54.95 \pm 0.72$ & $57.36 \pm 0.85$ & $700.35 \pm 1.12$ & $230.26 \pm 2.39$ \\
\hline 5 & $89.49 \pm 0.35$ & $66.34 \pm 1.03$ & $606.02 \pm 2.16$ & $211.80 \pm 1.93$ \\
\hline 6 & $71.19 \pm 1.66$ & $66.00 \pm 1.17$ & $600.44 \pm 18.30$ & $189.41 \pm 5.17$ \\
\hline 7 & $56.59 \pm 1.39$ & $60.10 \pm 2.54$ & $608.80 \pm 1.88$ & $204.59 \pm 6.23$ \\
\hline 8 & $79.58 \pm 1.09$ & $53.87 \pm 3.24$ & $623.05 \pm 6.70$ & $163.63 \pm 0.17$ \\
\hline 9 & $51.29 \pm 1.0$ & $42.22 \pm 0.13$ & $674.84 \pm 8.30$ & $218.47 \pm 0.05$ \\
\hline 10 & $64.45 \pm 1.88$ & $70.43 \pm 1.22$ & $696.40 \pm 2.42$ & $234.47 \pm 1.34$ \\
\hline 11 & $88.40 \pm 0.01$ & $68.30 \pm 0.77$ & $628.66 \pm 3.03$ & $157.63 \pm 5.32$ \\
\hline 12 & $125.56 \pm 2.95$ & $56.32 \pm 2.59$ & $651.50 \pm 12.11$ & $256.26 \pm 6.29$ \\
\hline 13 & $113.72 \pm 6.69$ & $68.18 \pm 0.19$ & $500.89 \pm 28.58$ & $249.79 \pm 7.24$ \\
\hline 14 & $122.14 \pm 8.65$ & $54.46 \pm 4.28$ & $624.4 \pm 19.63$ & $248.10 \pm 16.08$ \\
\hline 15 & $109.64 \pm 1.55$ & $74.45 \pm 1.76$ & $627.84 \pm 12.35$ & $264.45 \pm 2.92$ \\
\hline 16 & $92.13 \pm 9.16$ & $62.51 \pm 1.72$ & $640.02 \pm 24.01$ & $230.80 \pm 7.67$ \\
\hline 17 & $158.05 \pm 3.63$ & $72.88 \pm 3.01$ & $349.46 \pm 24.98$ & $289.18 \pm 9.50$ \\
\hline 18 & $87.78 \pm 6.44$ & $70.02 \pm 0.62$ & $582.23 \pm 11.12$ & $232.74 \pm 6.22$ \\
\hline 19 & $95.4 \pm 8.13$ & $77.10 \pm 1.21$ & $750.18 \pm 7.15$ & $263.42 \pm 10.40$ \\
\hline 20 & $72.64 \pm 3.49$ & $43.04 \pm 3.70$ & $689.94 \pm 9.86$ & $187.31 \pm 6.61$ \\
\hline 21 & $75.51 \pm 0.36$ & $43.06 \pm 2.47$ & $688.71 \pm 29.42$ & $190.12 \pm 5.92$ \\
\hline 22 & $99.88 \pm 8.27$ & $80.19 \pm 2.12$ & $728.28 \pm 18.57$ & $270.63 \pm 8.96$ \\
\hline 23 & $99.6 \pm 2.91$ & $77.80 \pm 2.31$ & $734.02 \pm 6.98$ & $267.37 \pm 5.52$ \\
\hline 24 & $85.2 \pm 6.62$ & $60.52 \pm 1.55$ & $738.15 \pm 14.99$ & $228.58 \pm 9.50$ \\
\hline 25 & $74.77 \pm 3.20$ & $44.92 \pm 2.75$ & $677.66 \pm 11.55$ & $191.19 \pm 3.61$ \\
\hline 26 & $132.71 \pm 4.56$ & $69.84 \pm 4.04$ & $632.31 \pm 24.46$ & $281.27 \pm 6.42$ \\
\hline 27 & $145.74 \pm 6.45$ & $73.91 \pm 0.47$ & $632.21 \pm 3.07$ & $300.11 \pm 6.75$ \\
\hline 28 & $138.80 \pm 5.06$ & $70.88 \pm 2.91$ & $672.52 \pm 4.46$ & $291.94 \pm 1.25$ \\
\hline 29 & $72.97 \pm 3.59$ & $52.54 \pm 2.64$ & $505.39 \pm 8.26$ & $187.02 \pm 7.43$ \\
\hline 30 & $141.52 \pm 2.83$ & $71.88 \pm 2.23$ & $632.83 \pm 18.77$ & $293.04 \pm 2.53$ \\
\hline Minimum & $37.50 \pm 0.33$ & $42.22 \pm 0.13$ & $349.46 \pm 24.98$ & $146.0 \pm 2.0$ \\
\hline Maximum & $158.05 \pm 3.63$ & $80.19 \pm 2.12$ & $750.18 \pm 7.15$ & $300.11 \pm 6.75$ \\
\hline Average & $92.23 \pm 31.39$ & $61.82 \pm 11.55$ & $621.84 \pm 97.89$ & $226.7 \pm 44.4$ \\
\hline
\end{tabular}


of raw material such as enriched potash feldspar minerals was also reported to contribute high concentration of ${ }^{40} \mathrm{~K}$ in tiles (Arafa 2004). Felsic minerals (quartz and feldspar) reported to responsible for the high concentration of natural radionuclides in tiles (Senthilkumar et al. 2014). Other raw material such as granite rocks also contributes to the high concentration of natural radionuclides in tiles (Al-Zahrani 2017). Some granite contains high natural radionuclides concentrations than other depending on the chemical composition and the formation of molten rock. The granite rocks are strongly enriched in uranium and thorium with different concentrations due to partial melting and fractional crystallization of magma that enables these radionuclides to become incorporated into the more silicarich product (US-EPA 1993).

It is common to evaluate radium equivalent activity $\left(\mathrm{Ra}_{\mathrm{eq}}\right)$ for non-uniform natural radionuclides in samples for estimation of the possible radiological hazard. A radium equivalent of $370 \mathrm{~Bq} \mathrm{~kg}^{-1}$ in building materials will produce an exposure of $1500 \mu \mathrm{Sv}$ year ${ }^{-1}$ to dwellers (Ahmed 2005). It is apparent that there is a significant variation of $\mathrm{Ra}_{\mathrm{eq}}$ values in the investigated samples as shown in Table 1 . The $\mathrm{Ra}_{\text {eq }}$ were found to be in the range of $146.0-300.1$ $\mathrm{Bq} \mathrm{kg}{ }^{-1}$, which lower than the recommended limit.

\section{RADIATION DOSE ASSESSMENT}

In order to evaluate the potential radiological dose incurred by an individual living in a building containing natural radioactive material particularly tiles, a Resrad-Build computer code was used. The minimum, maximum and average value concentrations were used as parameters to evaluate the dose received by dwellers for each investigated years $(1,5,10,20,50$ years) in six exposure pathways. The exposure pathways can be divided into external radiations exposure and internal radiation exposure. The external exposure pathways referred to direct exposure from source, exposure from deposited material on the floor and exposure due to air submersion. Besides that, the internal exposure pathways related to inhalation of airborne radioactive particulates, inhalation of radon gas and inadvertent ingestion of radioactive materials directly from sources and on the surfaces of the building components. The fractions of mean values of the six exposure pathways that contribute to the total mean dose exposure received by dwellers shown in Table 2 . The average total dose received by dwellers for 1, 5, 10, 20 and 50 years ranges from $2.21 \times 10^{1} \mu \mathrm{Sv}$ year ${ }^{-1}$ to $5.25 \times 10^{2} \mu \mathrm{Sv}$ year $^{-1}$, increased within the investigated timeline. Based on the finding, the primary radiation exposure route was through inhalation of radon gas. Radon gas was found to increase over the investigated years. This finding is in agreement with the previous study which reported that the level of radon in the old building is significantly much higher than the new building (Muhammad et al. 2009). As shown in Figure 2, radon gas contributes $80 \%$ from the total radiation exposure in the $1^{\text {st }}$ year and rise to $94 \%$ in the $50^{\text {th }}$ years. No increment in the radiation exposure due
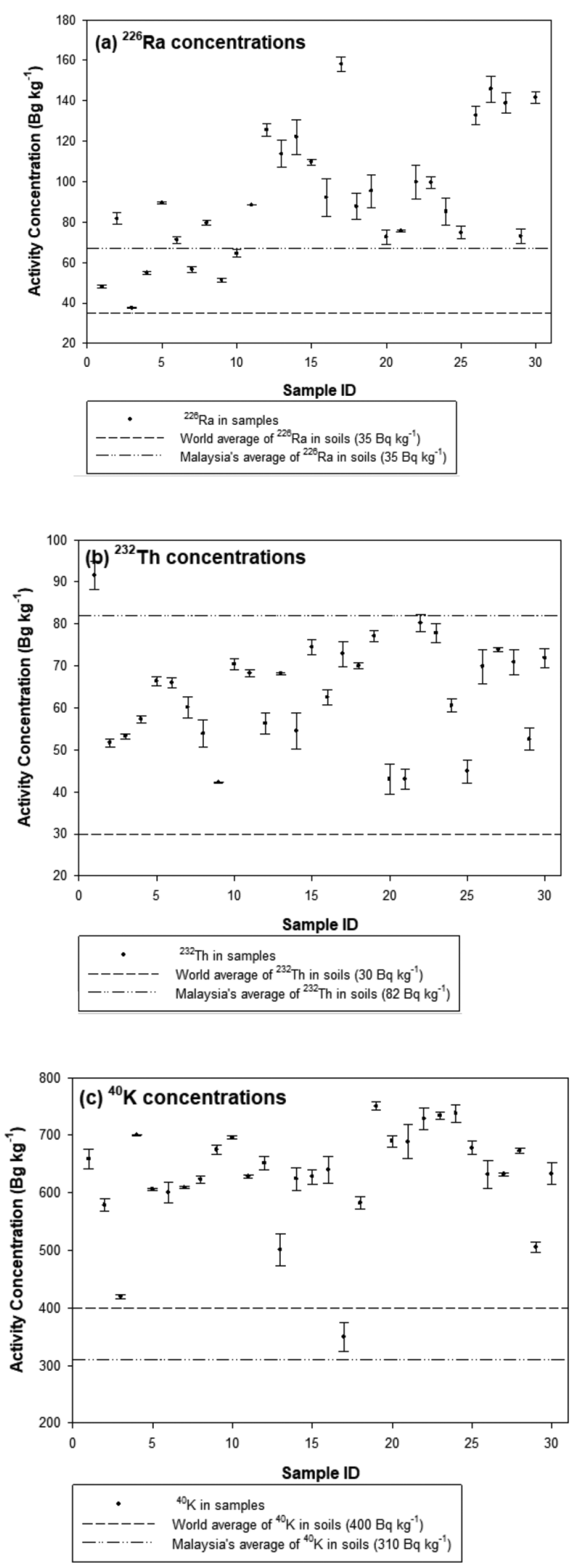

FIGURE 1 . Comparison of the activity concentrations of ${ }^{226} \mathrm{Ra},{ }^{232} \mathrm{Th}$ and ${ }^{40} \mathrm{~K}$ obtained in this study with average concentrations in soil as reported by UNSCEAR (2000) 
TABLE 2. Average dose exposure generated from Malaysia ceramic tiles

\begin{tabular}{|c|c|c|c|c|c|c|c|}
\hline \multirow{2}{*}{ Years } & \multicolumn{6}{|c|}{ Radiation dose exposure $\left(\mu \mathrm{Sv}\right.$ year $\left.{ }^{-1}\right)$} & \multirow{2}{*}{$\begin{array}{l}\text { Total dose } \\
\left(\mu \mathrm{Sv} \text { year }^{-1}\right)\end{array}$} \\
\hline & External & Deposition & Immersion & Inhalation & Radon & Ingestion & \\
\hline 1 & $2.21 \times 10^{1}$ & $2.64 \times 10^{-5}$ & $3.48 \times 10^{-7}$ & $1.62 \times 10^{-1}$ & $9.01 \times 10^{1}$ & $1.28 \times 10^{-3}$ & $1.12 \times 10^{2}$ \\
\hline 5 & $2.55 \times 10^{1}$ & $2.94 \times 10^{-5}$ & $3.93 \times 10^{-7}$ & $1.69 \times 10^{-1}$ & $1.98 \times 10^{2}$ & $1.62 \times 10^{-3}$ & $2.24 \times 10^{2}$ \\
\hline 10 & $2.90 \times 10^{1}$ & $3.22 \times 10^{-5}$ & $4.36 \times 10^{-7}$ & $1.77 \times 10^{-1}$ & $3.21 \times 10^{2}$ & $1.94 \times 10^{-3}$ & $3.50 \times 10^{2}$ \\
\hline 20 & $3.22 \times 10^{1}$ & $3.48 \times 10^{-5}$ & $4.75 \times 10^{-7}$ & $1.85 \times 10^{-1}$ & $4.40 \times 10^{2}$ & $2.93 \times 10^{-3}$ & $4.72 \times 10^{2}$ \\
\hline 50 & $2.34 \times 10^{1}$ & $3.58 \times 10^{-5}$ & $4.89 \times 10^{-7}$ & $1.88 \times 10^{-1}$ & $4.91 \times 10^{2}$ & $2.99 \times 10^{-3}$ & $5.25 \times 10^{2}$ \\
\hline 100 & $3.32 \times 10^{1}$ & $3.55 \times 10^{-5}$ & $4.85 \times 10^{-7}$ & $1.89 \times 10^{-1}$ & $4.91 \times 10^{2}$ & $3.25 \times 10^{-3}$ & $5.24 \times 10^{2}$ \\
\hline
\end{tabular}

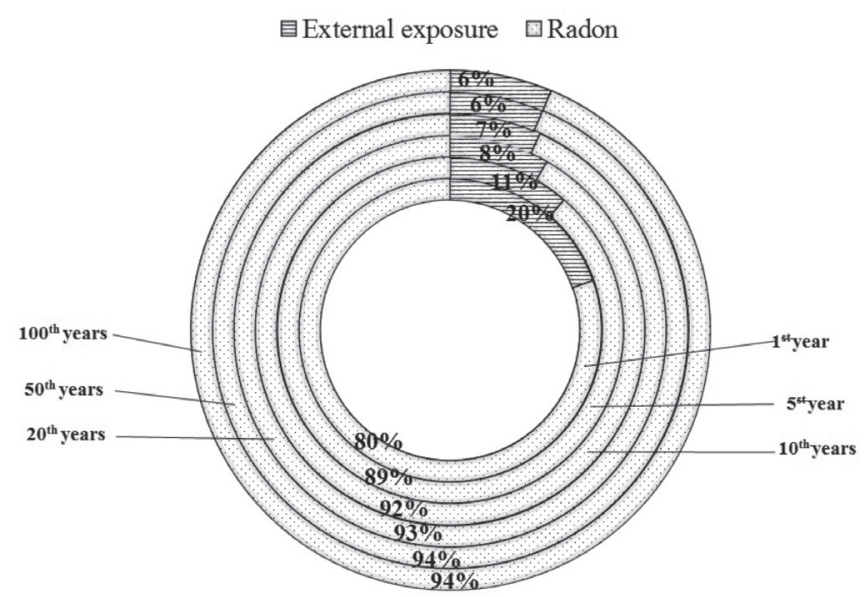

FIGURE 2. Comparison between radon and external radiation exposure due to natural radionuclides in tiles

to radon was observed in the $100^{\text {th }}$ years. The external exposure due to direct exposure from source contributes $20 \%$ in the $1^{\text {st }}$ year and declining to $6^{\%}$ in the $50^{\text {th }}$ years. Other exposure pathways did not significantly contribute radiation exposure to dwellers and might be neglected.

The radiation exposure was also estimated for minimum and maximum radiation exposure scenario based on the determined natural radionuclide concentration in tiles, as shown in Figure 3. All radiation scenario shows similar radiation dose increment in the investigated timelines. The projection of the radiation exposure shows that the annual effective dose of dwellers were increased for each studied years until it becomes stable in the $50^{\text {th }}$ years and above. The finding indicates that the level of radiation in the potential exposure scenario still lower than the recommended limit of $1500 \mu \mathrm{Sv}$ year ${ }^{-1}$ for building materials as suggested by NEA-OECD (1979). Even though the level of radiation exposure was below than the recommended limit, it should take into account that the dose was only contributed by tiles and not includes another type of building materials. For instance, the previous study in Malaysia reported that the annual effective dose generated from concrete building material could raise up to $540 \mu \mathrm{Sv}$ year-1 (Majid et al. 2013). Another study also indicated that the annual effective dose from other building materials in Malaysia such as

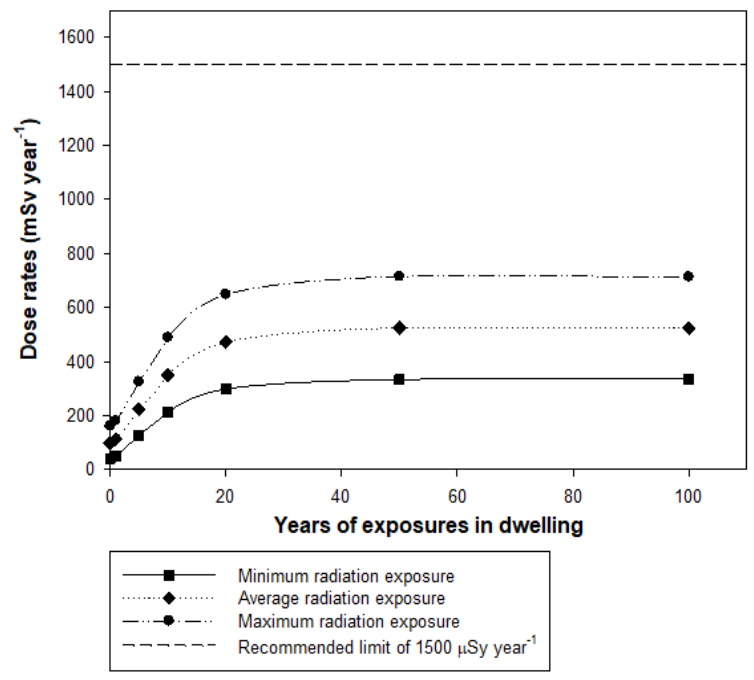

FIGURE 3. Projection of dose rates received by dwellers in Malaysia due to natural radionuclides in tiles

sand and gravel could reach up to 174 and $546 \mu \mathrm{Sv}$ year ${ }^{-1}$, respectively (Aznan et al. 2010). As the construction of building used several types of building materials, there is a possibility that summation of the total dose generated from several types of building materials might be higher than the recommended limit of $1500 \mu \mathrm{Sv}$ year ${ }^{-1}$. 


\section{CONCLUSION}

A total of 30 tiles samples have been analyzed for their radioactivity content. The activity concentrations of ${ }^{226} \mathrm{Ra}$, ${ }^{232} \mathrm{Th}$ and ${ }^{40} \mathrm{~K}$ were found to be much higher than the average world value of 35,30 and $400 \mathrm{~Bq} \mathrm{~kg}^{-1}$, respectively. Radium equivalent was found to be in the range of 146.0 - $300.1 \mathrm{~Bq} \mathrm{~kg}^{-1}$, lower than the recommended limit of 370 $\mathrm{Bq} \mathrm{kg}{ }^{-1}$.

The projection of annual effective dose received by dwellers using Resrad-Build computer code shows that the dose rates increase from the initial year to 50 years, but still below the recommended limit of $1500 \mu \mathrm{Sv}$ year ${ }^{-1}$. No significant increment for the dose rates observed after 50 years.

Based on this finding, it can be concluded that dwellers in Malaysia should not get any radiological complication due to natural radionuclides in tiles. However, it is recommended that further investigation on the level of natural radionuclides, radon and the radiation level for other types of building materials must be determined in the future to ensure the safety of dwellers in Malaysia.

\section{ACKNOWLEDGEMENTS}

The research was funded through ST-2017-012 and GGPM2017-084 research grants. The author wishes to thank all to Nuclear Energy Research Centre of UKM for their technical support throughout the works.

\section{REFERENCES}

Ahmed, N.K. 2005. Measurement of natural radioactivity in building materials in Qena City, Upper Egypt. Environmental Radioactivity 83: 91-99.

Almayahi, B.A., Tajuddin, A.A. \& Jaafar, M.S. 2012. Radiation hazard indices of soil and water samples in Northern Malaysia Peninsula. Applied Radiation and Isotopes 70: 2652-2660.

Al-Zahrani, J.H. 2017. Estimation of natural radioactivity in local and imported polished granite used as building materials in Saudi Arabia. Radiation Research \& Applied Science 10: 241-245.

Arafa, W. 2004. Specific activity and hazards of granite samples collected from eastern Desert of Egypt. Environmental Radioactivity 75: 315-327.

Aznan, F.I., Amran, A.M., Yasir, M.S., Redzuwan, Y. \& Bahari, I. 2010. Radiological risk assessment of concrete building material in Peninsular Malaysia. Sains Malaysiana 39(4): 607-613.

Beretka, J. \& Matthew, P.J. 1985. Natural radioactivity of Australian building materials, industrial waste and by products. Health Physics 48: 87-95.

Majid, A.A., Aznan, F.I., Yasir, M.S., Redzuwan, Y. \& Bahari, I. 2013. Radiological dose assessment of naturally occurring radioactive materials in concrete building materials. Radioanalytical Nuclear Chemistry 297: 277-284.

Muhammad, R., Saeed, Ur-R., Shahida, J. \& Muhammad, I.S. 2009. Measurement and comparison of indoor radon levels in new and old buildings in the City of Muzaffarabad (Azad Kashmir) Pakistan: A pilot study. Radioisotopes 58: 749-760.

NEA-OECD. 1979. Exposure to Radiation from Natural Radioactivity in Building Materials. Paris: Report by NAE Group Expert, OECD.
Nisha, S., Jaspal, S., Chinna, E.S. \& Tripathi, R.M. 2016. A study of the natural radioactivity and radon exhalation rate in some cements used in India and its radiological significance. Radiation research \& Applied Science 9: 47-56.

Raghu, Y., Ravisankar, R., Chandrasekaran, A., Vijayagopal, P. \& Venkatraman, B. 2017. Assessment of natural radioactivity and radiological hazard in building materials used in the Tiruvannamalai District, Tamilnadu, India, using a statistical approach. Journal of Taibah University of Science 11: 523533.

Righi, S. \& Bruzzi, L. 2006. Natural radioactivity and radon exhalation in building materials used in Italian dwellings. Environmental Radioactivity 88: 158-170.

Senthilkumar, G., Raghu, Y., Sivakumar, S., Chandrasekaran, A., Prem Anand, D. \& Ravisankar, R. 2014. Natural radioactivity measurement and evaluation of radiological hazard in some commercial flooring materials used in Thiruvannamalai Tamilnadu, India. Radiation Research \& Applied Science 7: 116-122.

Trevisi, R., Risica, S., D’Alessandro, M., Paradiso, D. \& Nuccetelli, C. 2012. Natural radioactivity in building materials in European Union: A database and an estimate of radiological significance. Environmental Radioactivity 105: 11-20.

Turhan, S., Arikan, I.H. \& Gungor, N. 2011 . Radiometric analysis of raw materials and end products in the Turkish ceramics industry. Radiation Physics and Chemistry 80: 620-625.

Thomas, G.H. 2000. Radioactivity measurement on glazed ceramic surfaces. Journal of Research of the National Institute of Standards and Technology 105: 275-283.

UNSCEAR. 2000. Exposures from Natural Radiation Sources. United Nations Scientific Committee on the Effects of Atomic Radiation. Report to General Assembly, with Annexes. United Nations, New York.

US-EPA. 1993. Carcinogenicity assessment. IRIS (Integrated risk information system), 2003. Washington DC, USA: US Environmental Protection Agency.

Xinwei, L. 2004. Radioactivity level in Chinese building ceramic tile. Radiation Protection Dosimetry 112: 323-327.

Yasir, M.S., Ab Majid, A. \& Yahaya, R. 2007. Study of natural radionuclides and its radiation hazard index in Malaysian building materials. Journal of Radioanalytical and Nuclear Chemistry 273: 539-541.

Aznan Fazli Ismail*, Shittu Abdullahi, Supian Samat \& Muhamad Samudi Yasir

Centre of Physics and Novel Materials

Faculty of Science and Technology

Universiti Kebangsaan Malaysia

43600 UKM Bangi, Selangor Darul Ehsan

Malaysia

Aznan Fazli Ismail*\& Muhamad Samudi Yasir

Nuclear Technology Research Centre

Faculty of Science and Technology

Universiti Kebangsaan Malaysia

43600 UKM Bangi, Selangor Darul Ehsan

Malaysia

Aznan Fazli Ismail*\& Muhamad Samudi Yasir

Nuclear Science Program

Faculty of Science and Technology 
Universiti Kebangsaan Malaysia 43600 UKM Bangi, Selangor Darul Ehsan Malaysia

Shittu Abdullahi

Department of Physics, Faculty of Science

Gombe State University, P.M.B. 127 Gombe

Nigeria
*Corresponding author; email: aznan@ukm.edu.my

Received: 15 September 2017

Accepted: 2 January 2018 